\title{
Levels of Cybersemiotics: Possible ontologies of signification
}

\begin{abstract}
In this article, it is argued that, in the making of a transdisciplinary theory of signification and communication for living, human, social and technological systems, C. S. Peirce's semiotics is the only one that deals systematically in an evolutionary perspective with non-conscious intentional signs of the body as well as with language. Thus - in competition with the information processing paradigm of cognitive science - this conception naturally gives rise to biosemiotics. This development has also spawned an interest in the possibility of defining levels of signification. The Cybersemiotic approach proposed in the present article integrates Luhmann's triple autopoietic theory of communication with pragmatic theories of levels and types of semiosis such as Intrasemiotics (between the psychic system and the biological self) and Thought-semiotics: the linguistic creation of a systematic and generative classification of the phenomenological, "silent" sign world. Finally a model of phenomenological reflection over "the hard problem of consciousness" called The Semiotic Star is suggested.
\end{abstract}

CORRESPONDENCE: Søren Brier. Department of Intemational Studies in Communication and Culture, Copenhagen Business School, Denmark. EMAIL: sb.ikkecbs.dk

\section{Introduction}

The goal of this article is to analyze the problems that our conceptions of science, up until the present, have raised for a natural evolutionary theory of signification involving levels of semiosis up to full language capacity. Furthermore, I will suggest solutions to these problems within the framework of Cybersemiotics, which combines Luhmann's autopoietic system theory with a Peircean biosemiotics, and with aspects of "embodied" cognitive semantics and ethology. I will draw heavily on the arguments presented by Brier (2008a) and use some of the models developed there. Still, the argument here is more focused on the question of how to develop a transdisciplinary framework where a scientific theory of nature and a phenomenological-hermeneutic theory of interpretation and meaning can be integrated with an evolutionary theory of levels of semiosis. 


\section{The dualistic problem}

Since Descartes, Western thinking has separated the subject and the object, and with Galileo and Newton it has mechanized the natural world and emptied it of meaning. In his Critique of Judgment, Kant realized that on the basis of a mechanical science of nature such as that of Newton, a proper theory of life could not be developed. Rather, living beings must, in Kant's view, be understood as self-organized autonomous systems. Kant never really drew the consequences of his discoveries for the rest of his philosophy. But at that time a theory of biological evolution was not something you had to work into your epistemology and ontology. Therefore there was no obligation to unite the areas of nature, mind, language, human consciousness and society in an evolutionary framework and to explain the qualitative differences between these as levels of emerging qualities.

Today we have seen a whole new foundation for a science of life emerge from what could be called Complexity Science (Prigogine 1980, 1996, Prigogine \& Stengers 1984, Kauffman 1995) ${ }^{1}$ sometimes combined with General Systems Theory (Bertalanffy 1976/68), or in part combined either with information science (Stonier 1990, 1992, 1997) or with second-order cybemetics (von Foerster 1984) and the theory of autopoiesis (Maturana 1988a, 1988b, Maturana \& Varela 1980) and sometimes with an organicist framework (Emmeche 2007). This approach reaches its full blossom in Niklas Luhmann's theory of Social System (1995), which attempts to integrate several of these approaches. Still even this approach has not succeeded in producing a fully consistent theory of signification (Brier 2007). Luhmann attempts to interpret Peirce's semiotics into

1 Ant colonies, bird flocks, rain forests, businesses, organizations, communities, the stock market and the global economy all have something in common. They are complex adaptive systems. Complex means composed of many parts, which are intertwined. Adaptive refers to the fact that all living systems dynamically adapt to their constantly changing environments as they strive to survive and thrive. Systems, because they are interconnected and interdependent and have emergent properties. "Complexity" represents the middle area between static order at one end and chaos at the other. Thus complexity is sometimes called the edge of chaos. The new science of Complexity evolved out of general systems theory and a field of study known as chaos theory popularized in James Gleick (1987), Choos: Making $A$ Nen Science. Complexity science suggests new models by which organizations can emerge, evolve and thrive in the increasingly complex environment. Life emerges at the edge of chaos; most of nature is nonlinear. The science of Complexity has to do with structure and order and is looking for the fundamental rules that underlie all these non-linear and self-organizing systems. The Santa Few institute is specialized in this highly computerized study that in its nonlinearity goes beyond standard mathematical analysis. 
his system theory (Luhmann 1999), but it can be argued that he loses Peirce's main points in the process (Brier 2008a).

It is seldom clearly contemplated within the humanities and social sciences that accepting evolution as a basic fact actually forces us into constructing a kind of unity of the sciences and humanities. So far this has only been attempted from a functionalistic and genetically centred view of nature such as that of Dennett (1991), which tries to eradicate the whole phenomenological aspect of human existence and understanding. Its promoters consider this theory to be an excellent solution and a victory for science and rationality. Other approaches such Activity Theory (Leontev 1977) and "first generation" cognitive science (Gardner 1985) also end up short in their inability to produce a theory of first person consciousness and the process of signification (Brier $1992,1995,1996,1997,1998 a$, and 1998b). On the other hand, the phenomenology of Husserl, Heidegger, and even Merleau-Ponty, the hermeneutics of Gadamer and the structuralist semiotics founded by Saussure have not been interested in the irreversible creation of radical new forms of life and mind through evolution. So, where can we find an evolutionary theory of signification, communication and the human self?

Another problem - seen from the evolutionary point of view - is that Kant, Descartes and arguably even Husserl accepted the notion of a transcendental subject as the focal point of all perceptions where they were brought together and given meaning. Despite considerable other differences, they all agreed that the subject was qualitatively different from the "outer world", though one could hardly accuse Husserl $(1997,1999)$ of dualism, since his central notion of the life-porld is intersubjectively constituted.

In the case of Kant's partly logically based categories, we are also left with the problem of the ontology of logic - if it is to be the foundation for our epistemology - as well as his silence on the role of the social and narrative aspects of language and their relations to first-person consciousness in producing meaning and rationality. Language did not play an important role in Kant's philosophy, as Zlatev (2008a) points out, and his different "worlds" were set apart as qualitatively different in the great Lord's creation. From a religious point of view this does not present a problem, since God unites everything in his wholeness, as also Spinoza claimed in his Ethics. But from an evolutionary point of view it is clearly problematic.

On the other side, first-person experience and awareness and the production of meaning and signification remain outside the scope of mechanicism, as it 
has developed since Newton. This even applies to the recent incarnation of this doctrine as a functionalistic, information-based, cognitive science. In order to allow the mechanistic sciences to be combined with modern evolutionary theory, the concept of "information" developed by Norbert Wiener (inspired by Schrödinger 2006 [1967]) needs to be integrated into the mechanical worldview at a level above matter and energy (cf. Brier 1992) by using thermodynamics as the basic foundation of physics. Thus, mechanics is left as a special and limited area of physics, only relevant for closed systems in equilibrium state that can be described deterministically by a state function. The necessity of this limitation became crystal-clear with Prigogine's pioneering work (Prigogine 1980,1986 , Prigogine \& Stengers 1984), which created an uproat in the physical sciences, even after he received the Nobel Prize. The "cure" - departing from mechanical classical physics as the general paradigm for a paradigm of complexity, chance, irreversibility and self-organization - was nevertheless unavoidable (Brier 1992, 1998a). The insights of Schrödinger, Wiener and later Prigogine \& Stengers (1984) were the basis for developing the informational and functionalistic approach of "life science". ${ }^{2}$ In itself it is, of course, a considerable step forward in the development of a scientific view of the mind. But, as pointed out earlier, in the informational extension of materialism there is no room for experiential first-person awareness, even if it is placed in a systems and cybernetic framework (Brier 1998a, 1998b). According to Dennett (1991), for instance, the mind ends up becoming a computer of sorts, creating (the illusion of) consciousness through the manipulation of "memes", Dawkins's (in)famous cultural parallel to genes. The so-called "hard problem" of how experience can come about from matter (cf. Chalmers 1996) is not resolved, but simply avoided or "explained" by supervenience, claiming that the experiential states of the mind depend on the physical states and properties of

2 The Origin of Life Program at the Santa Fe Institute seeks to understand how life began and its essential properties. To address these questions, SFI researchers have adopted a threepronged approach, asking whether life is a natural and perhaps necessary outgrowth of first principles in physics and chemistry, whether life can be synthesized, and what minimal life forms, such as viruses, can reveal about life's fundamental properties. The goal is to derive a definition of life that satisfies two criteria - one inclusive and one exclusive. The exclusion criterion should dichotomize the physical universe into living and non-living systems; whereas the inclusion criterion should accommodate all compelling empirical examples of life - from bacteria to protists, algae, flies, and mammals

Cf. <www.santafe.edu/research/topics-living-systems-dynamics.php> (15/6/2009). 
the brain. ${ }^{3}$ The same physical states will produce the same experiences. This does not offer an explanation of how awareness arises as a non-material quality in a material world.

\section{Semiotizing perception, cognition and the foundation of language through Peircean biosemiotics}

Having exhausted the alternatives, C. S. Peirce's semiotic philosophy seems to be the only place to turn if one wishes to include human consciousness in the theoretical foundation of an evolutionary theory that also contains a material world, living systems as well as language and the social-cultural world of intersubjective linguistic communication. In a Peircean biosemiotics (Brier 2008c), signification, communication and meaning as well as "qualia" are part of the foundation of the philosophy of signification from the start. In accordance with Peirce's semiotic phenomenology, which he calls phaneroscopy, an unlimited continuous stream of experiences (Firstness) is the force that gives rise to semiosis, when the momentary aspects of consciousness (Secondness) are related to one another through self-organization (Thirdness). Peirce assumed that feelings are inexplicable firsts, and that only when they are manifested in mind as individual expressions (Secondness) can they be related to each other and give rise to meaning through the regularity of this connection (Thirdness) as semiosis. A phenomenon has to emerge out of chaos and noise with some regularity (what he called "habit") in order to be interpreted as a sign of something else. Thus Peirce's phenomenological foundation is laid down in the following important passage:

No thought in itself, then, no feeling in itself, contains any others, but is absolutely simple and unanalyzable; and to say that it is composed of other thoughts and feelings, is like saying that a movement upon a straight line is composed of the two movements of which it is the resultant; that is to say, it is a metaphor, or fiction, parallel to the truth. [...] Whatever is wholly incomparable with anything else is wholly inexplicable, because explanation consists in bringing things under general laws or under natural classes. Hence every thought, in so far as it is a feeling of a

3 Supervenience is a central notion in analytical philosophy, involving a certain kind of dependency relationship, typically held to obtain between sets of properties in a manner, which does not imply a strong reductive relationship. For example, it has been claimed that human aesthetic, moral, and mental properties supervene upon physical properties, especially those of the brain. 
peculiar sort, is simply an ultimate, inexplicable fact. Yet this does not conflict with my postulate that that fact should be allowed to stand as inexplicable; for, on the one hand, we never can think, "This is present to me," since, before we have time to make the reflection, the sensation is past, and, on the other hand, when once past, we can never bring back the quality of the feeling as it was in and for itself, or know what it was like in itself, or even discover the existence of this quality except by a corollary from our general theory of ourselves, and then not in its idiosyncrasy, but only as something present. But, as something present, feelings are all alike and require no explanation, since they contain only what is universal So that nothing which we can truly predicate of feelings is left inexplicable, but only something which we cannot reflectively know. So, that we do not fall into the contradiction of making the Mediate immediable. Finally, no present actual thought (which is a mere feeling) has any meaning, any intellectual value; for this lies not in what is actually thought, but in what this thought may be connected with in representation by subsequent thoughts; so that the meaning of 2 thought is altogether something virtual. [...] At no one instant in my state of mind is there cognition or representation, but in the relation of my states of mind at different instants there is. In short, the Immediate (and therefore in itself unsusceptible of mediation - the Unanalyzable, the Inexplicable, the Unintellectual) runs in a continuous stream through our lives; it is the sum total of consciousness, whose mediation, which is the continuity of it, is brought about by a real effective force behind consciousness. (Peirce $\mathrm{CP}^{4}$ 5.289).

Here Peirce argues that it is not possible for us to contemplate the immediate immense stream of consciousness that is (the) Now'. We can only know the Now' by attaching signs to it afterwards, and this process is connected to the flow and arrow of time (Brier 2008d). Opposing the way Kant constructed his categories as being somehow inside the mind, Peirce uses his three basic phaneroscopic categories Firstness, Secondness and Thirdness at the basis of his theory of feeling and consciousness and thus connects them to his metaphysics in a unique and original way. In another passage he introduces the three categories on a phenomenological basis:

[...] first, feeling, the consciousness that can be included with an instant of time, passive consciousness of quality, without recognition or analysis; second, consciousness of an interruption into the field of consciousness, 
sense of resistance, of an extemal fact, of another something, third, synthetic consciousness, binding time together, sense of learning, thought. (Peirce CP 1.377)

Firstness, Secondness and Thirdness are thus three basic states of consciousness as well as "outer reality" developing in an evolutionary interplay with each other over time. ${ }^{5}$ Thus there is a deep connection between knowledge and time. This is connected to the foundational importance of irreversibility that destroys mechanicism as the basis of science. It also points to another thing that Prigogine (1996) and Peirce agree on: the reality of chance i.e., that chance is not only subjective (Brier 2008d). Innis (1994: 15) comments on how Peirce uses this insight in his semiotic theory of consciousness:

The time-constituted web of semiosis defines the life of consciousness, the meaning of which, as a chain of thought-sign and interpretants is what will be understood subsequently in another thought.

Another important point here is that Peirce's species of phenomenology, phaneroscophy, is "bom semiotic". There are no manifest experiences that do not have sign character since they combine the non-manifest qualia from Firstness with the manifest dual existence of Secondness (objects) and Thirdness (habit, regularity and meaning). Still the basic "feeling of what happens" (Damasio 2000) is there as Firstness in every sign connecting all signs to the continuum of Firstness (see Figure 1).

5 Like Husserl, Peirce was not a dualist, and therefore did not work with a framework where the distinction between "inside" and "outside" was primary. 


\section{INTERPRETANT (3. ness)}

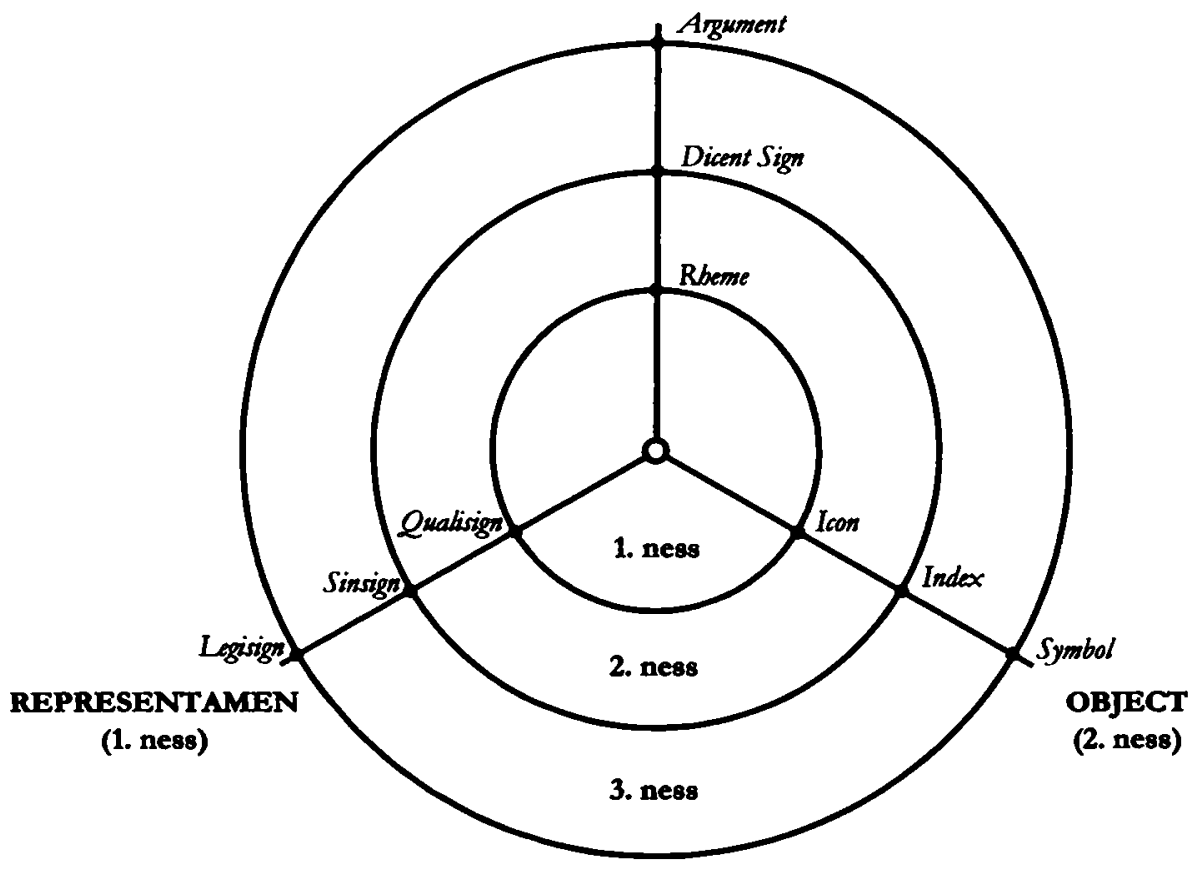

Figure 1. The three aspects of semiosis: Representamen, Object and Interpretant, making up the Peircean sign and bow they relate to Firstress, Secondness, and Thirdness. Peirce developed bis categories from this triadic model Each radial line from the centre corresponds to the parts of the sign relation: Representamen, Object, and Interpretant. Each leg is then made subject to triadic anabysis. Firstmess is closest to the centre, Secondness in the middle, and Tbirdness fartbest away from the centre. The nine "pure sign types" (or valencies) are then combined three at a time into ten classes of actually manifesting signs. (From Brier 2008a, where further explanation is provided).

Thus feelings understood as potential qualia - being an intrinsic part of Firstness - are the basic and atomic qualities of the world. As Peirce was a synechist (a continuum thinker) he viewed consciousness and matter as two ends on a continuum. He referred to matter for "effete mind" (see below), which is a concept that is among his less developed. One way of explaining it is to say that it is at the opposite end of a continuum of which living mind is at the other end. Peirce's triadic semiotic "objective idealism" levels mental and physical phenomena into a single ideal system of evolutionism and synechism. Synechism is the tendency to regard everything as continuous. This includes mind and matter as well as individual embodied and social mind. "All commu- 
nication from mind to mind is through continuity of being" (Peirce CP 7.572). ${ }^{6}$ The so-called "material universe" is made up of effete mind and develops towards a crystallized mind. Thus effete mind is something, which can grow, become mature and crystallize. Thus mind and matter are, so to say, folded into each other in what is known as bylozooism. ${ }^{7}$ Peirce clarifies the concept of feeling as follows:

By a feeling, I mean an instance of that kind of consciousness which involves no analysis, comparison, or any process whatsoever, nor consist on whole or in part of any act by which one stretch of consciousness is distinguished from another, which has its own positive quality which consist in nothing else, and which is of itself all that it is, however it may have been brought about; so that if this feeling is present during a lapse of time, it is wholly and equally present at every moment of that time. To reduce this description to a simple definition, I will say that by a feeling I mean an instance of that sort of element of consciousness which is all that is positively, in itself, regardless of anything else. (Peirce CP 1.306)

For Peirce, feeling is the basic quality of immediate consciousness having its own quality, independent of any other state of mind; it is perfectly simple in itself. ${ }^{8}$ Consciousness is built up by feelings (Firstness), perceptions (Secondness) and significations (Thirdness) combined in semiosis, allowing for various levels of consciousness in living systems.

6 Mladenov (2004) was an inspiration for this explication of Peirce's philosophy.

7 This is a view that Peirce shares with Aristotle. In philosophy "hyle" refers to matter or stuff; the material cause underlying change in Aristotelian philosophy. It is what remains the same in spite of the changes in forms. In opposition to Democritus' atomic ontology, hyle in Aristotle's ontology is a plenum or a sort of field. Aristotle's world is an uncreated eternal cosmos, but Peirce used the term in an evolutionary philosophy of a world that has an end and a beginning. The English term was introduced by Ralph Cudworth in 1678. Hylozoism in this context - is the philosophical conjecture that all or some material things possess life, or that all life is inseparable from matter. It was a doctrine held especially by early Greek philosophers. Hylozoism is different from the panpsychist idea of everything possessing a soul, but it does attribute some form of sensation to all matter, very much like Whitehead's panexperientialism. Hylozoism it is not a form of animism either, as the latter tends to view life as taking the form of discrete spirits. Scientific hylozoism is a protest against a mechanical view of the world as dead, but at the same time upholds the idea of a unity of organic and inorganic nature and derives all actions of both types of matter from natural causes and laws.

8 One of the referees finds this to be contradicting my use of Lakoff \& Johnson (1999) to demonstrate the role of embodiment in meaning production in sign games and language games. But I only accept their theory as an attempt at a scientific explanation, which is in a need of a philosophical foundation, such as Cybersemiotics. Lakoff does not see it this way and tries to find support directly in brain science (e.g., Gallese \& Lakoff 2005). I acknowledge their pioneering work on embodiment and embodied cognitive semantics, but more theoretical and conceptual development is needed in this difficult area. 
Since my voyage into Peirce's semiotics began from the problems Konrad Lorenz (1977) encountered trying to include the first-"person" experience of animals in instinctively motivated behaviour into a causal model, I will start at the level of zoö-semiotics. Lorenz realized that he could not introduce first-person experience as having any causality in a scientific materialistic world-view or for that matter in a dualistic one. But he stopped there. My argument is that Peirce offers a new paradigmatic framework that makes it possible to integrate emotions and causality.

Here the work of Ellis and Newton (1998) on the role of not explicitly selfconscious purposeful emotionally steered behaviour in animals seems very promising. Ellis and Newton started a new line of research into consciousness when they took up the problem of motivation and emotion where Lorenz left it. They recognize emotion and purposefulness as real:

Emotions and motivations are characterized by purposive strivings, and there do seem to be non-conscious yet purposive phenomena in nature, especially in biological organisms. The human organism purposely does what is needed to regulate heartbeat and blood pressure, yet normally is not conscious of doing so. Merleau-Ponty defines a "purposeful organism" as one that changes, replaces, or readjusts the functioning of its own parts as needed to maintain or enhance the functioning of the whole organism. (Ellis \& Newton 1998: 434)

Thus a lot of a living system's purposeful behaviours and actions are not selfconsciously experienced. Much of our purposeful behaviour of the body is so hardwired that it will take a lot of training with biofeedback or yoga to be able to be so consciously aware of it that we can control it by our free self-conscious will. This view of purposefulness of living systems can be used to supplement the missing aspects of Lakoffs and Johnson's (1999) view of the body. Their "embodied realism" does not deal with animal cognition or an evolutionary connection between it and the development of human cognition and categorization. Their "conceptual metaphor theory" assumes that so-called "primary metaphors" are grounded in bodily experience, but it is unlikely that this can be modelled in a mechanical way on the basis brain regions and networks, as proposed by Gallese and Lakoff (2005). A semiotic approach - biosemiotics seems more warranted, which is consistent with the claim of Ellis and Newton that: 
[...] emotions are conscious only to the extent that we form some sort of representation of what they are about and of how they are manifest in our bodies. Usually, this entails imagery of some sort, especially when we consider symbolic utterances as a kind of imagery [...] Both emotion and representation are needed for phenomenal consciousness. Without emotion, we might have unconscious information processing, as in a digital computer or thermostat or thermos bottle; and without the representation, we might have unconscious emotions, as in "wanting" to fill or empty the outer electron shells of atoms in the various biological systems, so as to restore chemical homeostasis, but not a conscious wanting of this outcome. But emotion and representation must be present for phenomenal experiencing to occur. (Ellis \& Newton 1998: 435)

Thus Ellis and Newton seem to use concept of emotion in an ontologically basic way much like Peirce where emotion as the basis of consciousness develops from an unaware subconscious level to a conscious level in the evolution of livings systems. Ellis and Newton argue for going beyond physiochemical explanations to include the phenomenological (and social) semiotic view as a way of explaining the foundations of cognition and semiosis. This foundation is necessary for understanding how a self-conscious being can master human signs and language. Again I claim that it is not possible to be consistent here without accepting Peirce's broader foundation that provides an alternative to mechanicism. It is also difficult to see how metaphor-based conceptualization as that proposed by Lakoff and Johnson (1999) can be possible without a body-mind driven by emotional motivation:

In anticipating perceptual objects, we are anticipating the way they may or may not interact with our motivating organismic purposes. There is no attention without motivation to attend, and no motivation without emotional purposes. Furthermore, part of the anticipated outcome in action planning is the hoped-for or feared subsequent emotional state of the organism. (Ellis \& Newton 1998: 438-39)

Human beings and animals are always anticipating meaningful contexts connected to their forms-of-life. It is the inability to extract the person from his embodiment that anchors meaning in our psycho-biological being as something to be classified and developed by language and culture (Brier 2005). This is also clear in the development of the idea of the role of the body from Husserl to Merleau-Ponty's "naturalized" phenomenology. Therefore biology matters. But a mechanistic molecular biology does not have the philosophical, especially the 
ontological, foundation capable of explaining the inner experience of biological systems, their cognition through signification, and their capacity for communication, leading through evolution to the foundation of human language. For this, biosemiotics seems necessary.

\section{The biosemiotic perspective}

Biosemiotics $^{9}$ is the scientific study of signs, biological codes and semiosis in living systems, compatible with C. S. Peirce's theory of triadic semiotics, ${ }^{10}$ which implies that cognition and communication among all living systems involves signs. Let me give just two illustrative examples.

- Blackbird song may be considered as sign-based communication since it contains information concerning the species of bird, its territorial claim, its improvisational skills and even its location (since it often has dialects). But the meaning of these signs will depend of the knowledge and level of consciousness of the interpreter, and thus will differ for e.g., other blackbirds and ornithologists.

- In molecular biology, biosemiotics considers hormones and transmitter molecules as signs with material vehicles, since their effect (1.e., interpretant) depends on the type of cell receiving them: the kind of receiver channels it has, their number, in what tissue the cell is, and where the cell is in its life cycle (Hoffmeyer 1996, 2008).

Biosemiotics transcends on the one hand the purely chemical description of life present in molecular biology and, on the other hand, the traditional idea that semiotics is only the study of signs in the language and culture of human beings. Instead biosemiotics includes the whole realm of biology in semiotics. Life and semiosis are seen as co-extensional. Biosemiotics attempts to integrate the findings of biology and semiotics to form a new view of life and meaning as immanent in the natural world. The biosemiotic strategy is to focus on sign systems and codes instead of laws. A code is a set of process rules or habits (e.g., the working of ribosome) that connects elements in one area (e.g., DNA)

9 Introductions to biosemiotics and its history can be found in many places, but let me here point to a few good articles in the first issue of the new Joumal of Biosemiotics. Barbieri (2008), Favareau (2008), Hoffmeyer (2008) - as well as Kull (1999).

10 Marcello Barbieri (2001), who developed the theory of biological codes mentioned in the next section, has not done so on a Peircean basis. 
with another area (e.g., sequences of amino acids in proteins) in a specific meaning context (here the creation, function and survival of the cell). A code gives meaning to differences or information in certain contexts. Language depends on social and cultural codes. To most biosemioticians it is crucial that the correspondence is not an objective universal natural law (if such exists) but a local contextual phenomenon that is defined by some kind of motivated interest on the level of animals and on the human level from an interpersonal, cultural convention. In contrast, machines do not make codes themselves. A sequence of differences such as the base pairs in DNA can be information for coding, but is not a code in itself. Peircean biosemiotics argues that codes are part of triadic sign processes where an interpretant makes the motivated connection between objects and representamens. Living systems function on the basis of self-constructed codes.

The proteins in the living cell are different from proteins created through external spontaneous chemical processes. Living systems are not "natural" in the same way as physical and chemical systems, because their protein molecules are self-constructed by molecular machines (the ribosomes and connected processes). Cell proteins have the sequences of their amino acids determined by the internal code system in the cell in the manner clarified above. The structure of living systems, their organization and processes, are determined by internal codes and they are therefore in a certain way "artificial". Thus we here shift the border between natural and cultural from between human society and the rest of nature to being placed between living systems and the rest of ("non-living") nature. This is because the essential macromolecules that create living systems and are created by living systems in autopoiesis are not found outside living systems. Culture starts with biosemiosis. Since social sciences and humanities have defined the many meanings of culture (cf. Hornborg this volume), we might better call it the level of biosemiotics culture. This concept of culture is created within the research program of biosemiotics. Living systems are a kind of materially based discursive systems. By including the living systems in the semiotic realm and also realizing that they are to an important degree selfconstructed, the first part of the gap between nature, mind and culture is mended.

Biological systems are then understood as being communicative structures or sign-yyborgs because they are made of coded molecules and are organized communicatively by semiotic processes. The behaviour of organisms represents neither intemal "organization" nor external "information" but interpretations of the first in terms of the second in the phenotype as well as the genotype. 
Hoffmeyer and Emmeche (1991) argue that living systems are based on codeduality (Emmeche 1998). They are not machines controlled alone by a "selfish gene" (Dawkins 1976), but reproduce and adapt themselves by an ongoing exchange between the digital genotype of the DNA and the analogue phenotype (the whole autopoietic organism). This is a kind of cybernetic feedback dynamics based on semiotic codes. This semiotic dynamics establishes the bodily basis for human consciousness and the generative language games that in their exchange with life forms create the cultural dynamics. We can call humans language-gyborgs because our minds are "artificially" formed by language.

The evolution of life thus is not only based on physical, chemical and even informational processes but also on the development of semiotic possibilities or the enlargement of semiotic freedom, as Hoffmeyer (1998) calls it. Signs are the basic units for the study of life. Organisms do not only make ecological niches, they make "semiotic" ones (Hoffmeyer 1998, 2008) in the form of signification spheres (Brier 1995). Subjectivity and meaning are always produced by embodied beings with some kind of individuality and interest that orders perception in terms of functionality and survival. But how does that influence language and culture? What are the relations between the biological, psychological and the socio-cultural levels? The particular development of biosemiotic theory known as Cybersemiotics (Brier 2005, 2008a) offers some answers to these questions.

Both biosemiotics and embodied cognitive semantics (Lakoff 1987, Lakoff \& Johnson 1999) have argued extensively for the importance of embodiment in semiosis (Brier 2001a), and can be integrated into a common framework (Brier 1999). This is necessary in order to show how some basic emotional processes may be transferred to language from the embodied sign games of living systems.

Brier (1995) explores the connection between ethologically based concept of motivation and the emotional-phenomenological aspects that Ellis and Newton (1998) so convincingly introduce. To establish such a connection between concepts of motivation and phenomenological ones requires a Peircean biosemiotic foundation, producing an integrated unity of the motivation concept of Lorenz (1977) with a first-person experience of feelings and the "image schemas" and "metaphors" of embodied cognitive semantics. The outer behaviour and the formal aspects of cognition can thus be combined with an inner experiential aspect. These elements together then produce the foundation for interpretation and meaning (See Figure 2). 


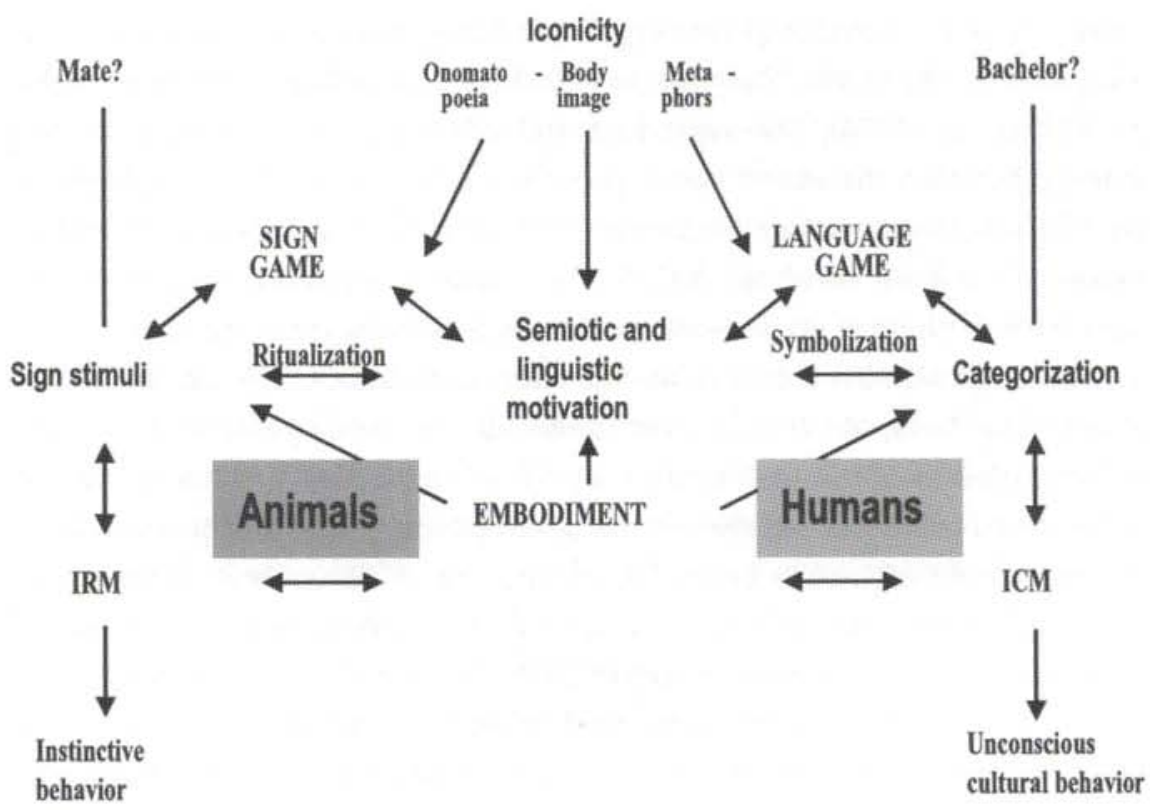

Figure 2. The relation between buman linguistic motivation and instinctive motivation in animal behaviour by relating animal and buman signification through a Cybersemiotic framework. It is suggested that although animals do not have language games, they bave sign games. Semiosis is thus functioning on two different levels in animals and bumans. But in both cases it is embodied, and basic biological motivation bas a role to play, although other forces are also influential on the linguistic level. The figure points to the similarity between the ethological concept of IRM (innate release response) and the cognitive semantic concept of ICM ("idealized cognitive model") and postulated structures guiding motivational attention and iconicity (based on Figure 12 in Brier 2000).

I suggest that the ethological motivation behind the sign game of mating, through its emotional embodied aspect, encounters and integrates with the linguistic motivation behind the term bachelor. Even though the "idealized cognitive model" (ICM) concept (Lakoff 1987) has practically disappeared in cognitive semantics, probably due to its vagueness, the main idea is the same. However, the very simplified concept of "embodiment" used by Lakoff and Johnson (1999) with no ethological and biosemiotic background or framework is not enough. Embodiment needs to be experientially connected to biopsychological functions. The first emotions come from these instinctual IRMs and they later become conscious feelings. A basic early function in embodied motivation develops into metaphors and later far more abstract thinking (thus, there is development from left-to-right in Figure 2). Brier (1999) argues that a (biosemiotic) conception of a sign as something standing for something else for somebody in a particular way connects the two kinds motivation (instinctive and 
linguistic), experience, perception and behaviour. Instinctually, the actual IRM (Innate Release Mechanism) influences the cognitive forms that will release the connected behaviour through the urge coming from a specific motivation. This is again based on biological expectancies and vital needs, like food and mating. The "embodied" linguistic motivation that is claimed to control ICMs in human cognition connects to the biological motivations in many instances (Lakoff 1987). This is obvious in the linguistically much-used example where a woman classifies a man as a "bachelor", which is a cultural concept filled with social expectancies, but that is defined in relation to the basic biological motivation of searching for a potential mating partner in order to produce offspring. It is our bio-psychological embodiment that ties these relations together. But how can we understand this scientifically on the basis of evolutionary theory? In cognitive science there is really no other answer to this than to skip over the experiential part and use informational terms, e.g., "neural computation" (Lakoff \& Johnson 1999).

Can biosemiotics present a compromise where life and semiosis coincide, while still not explaining the emergence of life and mind through pre-biotic semiosis in nature in some sort of pan-semiotics? Some biosemioticians, such as Emmeche (2007), have stressed the organicist view with its theory of emergence based on Complexity Science, which features the concept of complex adaptive system (CAS) as a solution. The term CAS means an open system in a thermodynamic gradient (i.e., one far from the equilibrium). This is in part what Prigogine (1980) called "dissipative structures" but with many non-linear connections, and feedback mechanisms added. These systems are pre-stages to memory functions; they often have complex dynamic networks, which are locally differentiating and have emergent and holistic properties. Still, I would argue that these concepts need to be placed on a Peircean foundation, since I am unable to see how a physicalistic evolutionary foundation combined with the idea of emergence can function to make consciousness appear from totally inert matter in autocatalytic closed circuits (Kauffman 1995).

Knowledge systems unfold from our bio-psycho-socio-linguistic conscious being. Their function is to help us orient ourselves in the world and help us act together in the most fruitful way. We think with "the body in the mind" Johnson 1987) as foundation for the semantic aspect of language. The psyche and its inner world arise within and between biological systems or bodies. One may say that there will always be some kind of psyche in any kind of biological autopoietic and code dual system. Still, a partly autonomous inner world of emotions, perceptions and volitions only seems to arise in multi-cellular 
chordates with a central nervous system. Lorenz (1977) argues that such a system with emotions and experiences of pleasure is necessary for animals to have appetitive behaviour, searching for the objects or situations that can elicit their instinctual behaviour and releasing the motivational unge built up behind it, giving rise to pleasurable feelings. This is qualitatively different from how reflexes function as signals, at a proto-semiotic informational level. The latter only need a general arousal of the Reticular Activation System in order to function. The coordination of organisms with each other through reflexes constitutes the lowest level of communication. The sign function of instincts demanding a specific felt motivation, on the other hand, is on a genuine semiotic level. Finally, biosemiotics also works with endosemiotics, sign communication inside the body, i.e., communication between various tissues by the way of sign molecules (Hoffmeyer 2008).

\section{Cybersemiotics: Information and cognitive science combined with Peircean biosemiotics}

There cannot be a theory of signification without a theory of mind that places consciousness centrally in one's ontology. What kind of framework is necessary to develop such a theory of signification in the "Age of Science", when science thinks that it has finally conquered religion and spirituality? There seem presently to be three such basic frameworks:

1) One is based on a cybernetic informational worldview, of the kind founded by Norbert Wiener, but possibly also combined with an organicist philosophy inspired by Ludwig von Bertalanffy and cybernetics. One can here seemingly still accept some kind of physicalistic basic ontology, and postulate that complexity drives the emergence of life, followed by cognition, a process that in the end makes consciousness, qualia and feelings possible. ${ }^{11}$ Gregory Bateson's theory represents one of the most advanced forms of this framework. It is based on the idea of an ecological cybernetic mind and the concept of information as a "difference that makes a difference" in circular systems, which tie the living system to its environment through informational correlation and integration. This system was what Bateson called "mind" and which he

11 Presently existing theories of emergence do not seem offer us a way to understand the emergence of "mind from matter", if our definition of matter is as something dead and inert, or on the basis of an information science approach that sees information as objective structural differences in matter or between parts of matter (Brier 2003). 
in an evolutionary theory saw as "an ecology of mind": "the pattem that connects" the human with animate and inanimate nature in what we could call "the divine" (Brier 2008c).

2) The second framework is that of autopoiesis, i.e., self-creating organizationally closed systems (Maturana \& Varela 1980, 1986), which is in opposition to the cybemetic informational world view. This theory has not been fully philosophically developed, but maybe one can say that its ontology is open but realistic, a kind of bio-constructivism. Still, it has no theory of mind as first person experience with qualia, emotions and will. At least Maturana's way of dealing with things (Maturana 1988a, 1988b) seems to be a blend of behaviourism and constructivist cognitivism, criticized for this by e.g., Bains (2006). Varela, Thompson and Rosch (1991) initiated a new development within this framework, introducing concepts such as "embodiment" and "enaction". But it is first Thompson (2007) that has attempted to integrate a Husserlian phenomenological aspect into the theory. However, as pointed out in the onset of this article, Husserl himself did not try to integrate phenomenology with an evolutionary world view.

3) The third framework is Niklas Luhmann's triadic autopoietic system theory, which attempts to integrate the two previous ones. Luhmann tried to solve the problem of qualia and first person consciousness, and its involvement in communication and language, by introducing an understanding of the psyche and the socio-communicative system as autopoietic systems (See Figure 3). He attempted to integrate Bateson's cybemetic theory as well as Husserl's phenomenology into his communication model. His epistemology and a vague ontology are both taken from Spencer-Brown's "Laws of form" (Spencer-Brown 1979), where the observer is basic in making the first distinction. Consciousness is accepted in an open ontology, but the unification of the various frameworks of Wiener-Bateson, Maturana, Spencer-Brown, Bertalanffy and Husserl seem not to be carried through in a philosophically consistent way (Brier 2007). The question remains: how and where can we place mind, matter, information and signification in such an inter- or even transdisciplinary framework (Brier 2006)? 


\section{AUTOPOIESIS}

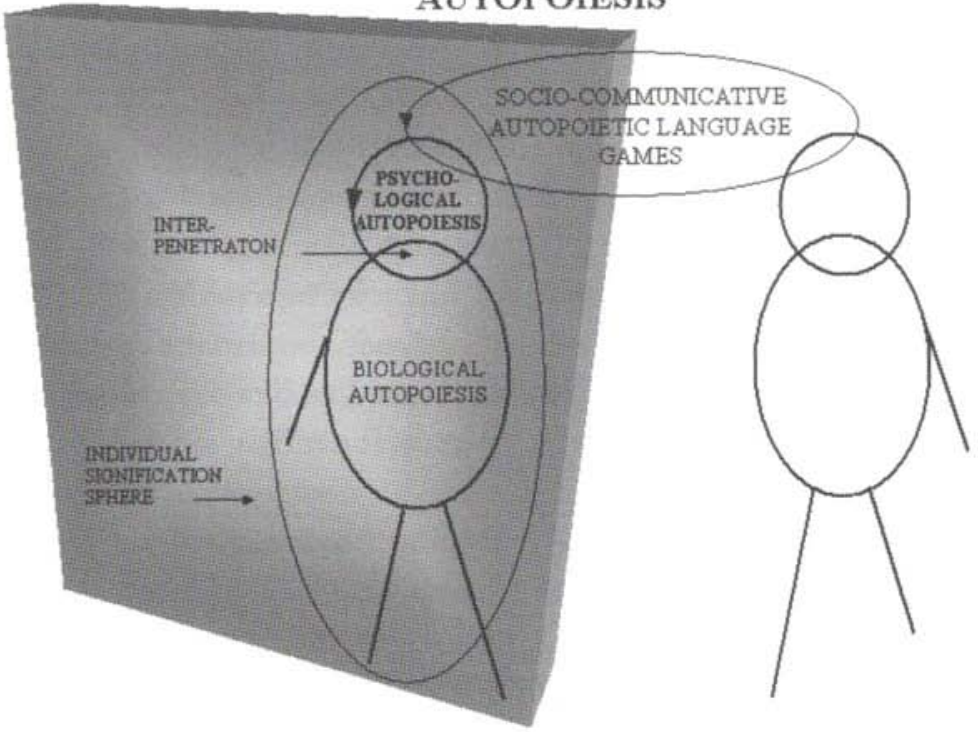

Figure 3. This is an illustration of Lubmann's triple autopoietic model for communication. Schematically, the body is shown as involving biological autopoiesis and the bead as the psychological and the socio-communicative system as working between buman beings (intersubjectivity). The signification sphere is a gyersemiotic concept delineating the cognitive domain of a living system from the rest of the enviromment, which is basically experienced as noise. The tbree autopoietic systems bave mutual structural couplings, wbich make linguistic, meaningful expressivity possible (Based on Brier 2008).

As biosemiotics is trying to build its disciplinary matrix, it becomes clear that there are disagreements about what it takes to produce signification. There seem to be differences in philosophical frameworks especially in the stipulation of ontology and epistemology and their relational interdependence. Some researchers seem to think that they can stay in a physical paradigm relying on classical physics, thermodynamics and quantum mechanics, while others think that a cybernetics-informational paradigm will fulfil their requirements (Deacon 2007 and 2008). ${ }^{12}$ Still others seem to think that some kind of second-order cybernetic-autopoietic paradigm like Niklas Luhmann's is sufficient to solve the mystery of signification, meaning and understanding (Luhmann 1992, 1999)..$^{13}$

12 This was also my impression from the lecture given by Terrence Deacon in Copenhagen 2007. See also Sonesson's (2006) critique of Deacon's (1997) interpretation of Peirce's semiotics.

13 Ort \& Peter (1999) make a pretty strong analysis of Luhmann's lack of understanding for Peirce's semiotic idea, and one can in Luhmann (1999) see how he attempts to reduce Peirce's triadic semiosis to his own dyadic system. Some reasons why Luhmann does not 
According to Luhmann, a message consists of three aspects: (1) Information, (2) Utterance, and (3) Interpretation. But Luhmann did not develop the semiotic process of signification in order to understand the production of meaning through signification. Instead he tried to import a field of meaning through a systemic reinterpretation of Husserl, with the psychic and the sociocommunicative systems used as medium. ${ }^{14}$

The construction or development of meaningful messages certainly has autopoiesis, interpretation and motivation/intentionality as prerequisites. In the paper on phenomenal consciousness in animals quoted earlier, Ellis and Newton (1998: 431) write:

It is the organism's emotions that motivate it to act on its environment rather than merely react, the pbenomenal aspect of conscious experience requires the organism's emotionally motivated action in relation to the perceived world, particularly in its interest in selecting for attentional focus. If the organism's knowledge of its environment is to involve a "fall" dimension, in the sense that there is "something it feels like" to have a state of consciousness, the conscious processing must first flow from an emotional process within the organism, which pre-exists to any particular input, and puts its qualitative stamp on each selected input.

We are suggesting that the "fell" aspect of experiencing is tied in with the fact that organisms are emotionally motivated to "look for" elements of the environment that are significant with respect to the organism's motivational purposes; that the organism "anticipates" experience in terms of motivational categories which preselect for attention; and that the emotions that guide this anticipation and selection process are a major contributor to the conscious feeling of "what the consciousness of suchand-such an object is like".

Viewed in this way, ${ }^{15}$ Luhmann's (1990) three autopoietic systems are all needed to create the meaning of a message, and one needs the sign concept to understand their interaction. Within the Cybersemiotic framework, one way of

manage to incorporate Husserl's theory into his autopoietic system theory are given by Brier (2007).

14 It is only within this triad that the selections of information, utterance and meaning are possible. Luhmann's theory has problems producing a concept of meaning that relates deeply to the flesh, blood and life (conditions) of biological systems and the existential conditions of human consciousness. Here embodied cognitive semantics (Lakoff 1987, Johnson 1987) combined with ethology, as suggested in the previous section, can be of help.

15 The problem within a Husserlian paradigm is that the phenomenological view is here enlanged to encompass living systems and as such integrated with a scientific theory of evolution. That is only possible on the basis of Peirce's semiotic phaneroscopy. 
getting out of the impasse of Luhmann's functionalism, where the role of body and mind in the production and meaning of social communication has not been adequately grasped, is to view the interpenetration between the three onganizationally closed systems as a semiotic pbenomenon. Signs acquire meaning where the systems interpenetrate. ${ }^{16}$ But to accept this, one has to integrate Luhmann's paradigm into Peirce's semiotic-philosophical system, described earlier.

From the Cybersemiotic point of view, sign and language games arise on the basis of the interpenetration of the autopoietic systems in such a way that three levels of communication result: (1) A behavioural reflexive level of bodily coordination, e.g., when fish calibrate their movement in a school or turntaking between mother and baby. (2) A level of instinctively based sign games depending on motivated anticipatory felt significations, e.g., mating games, singing competitions among black bird males, the coordination in hunting among lions. (3) The socio-linguistic level based on language games.

Autopoiesis theory underlines that two interpenetrating systems are closed "black boxes" to each other. But Maturana and Varela suggest that interpenetration develops over time, causing a coordination of behaviour that they call "languaging". Maturana's concept of languaging is the biological connection between two individuals in a social species, not the sign or language games as such; the cognitive coupling is the necessary environment for the development of communication as a signification system with its own organizational closure. We should therefore distinguish between language games, sign games, and the level of reflexes: languaging. The perception that elicits reflexes is independent of motivation, whereas the perception of sign stimuli is dependent on motivation that leads to instinctual sign games. Ethologists would here highlight how particular instinctual movements become ritualized and acquire a signal release value for instinctive behaviour as "sign-stimuli". In his later work, Lorenz (1977) hypothesized that emotions are connected to forming and urging instinctual movements, thus constructing connections between signs and internal or phenomenological understandings in the form of the creation of interpretants. And Lakoff (1987) and Lakoff \& Johnson (1999) propose basic mechanisms for transferring bodily meaning into a foundation for language on the basis of "image-schematic" and metaphorical processes that encompass socially and culturally produced signs.

16 "Interpenetration" is Luhmann's term for the interplay between biological autopoiesis, the psychic closure and the socio-communicative system with its own closure at the social level, when they are not only structurally coupled but actually can use each other as resources. 
Luhmann's theory of the human socio-communicative being as consisting of three levels of autopoiesis can thus be used by Cybersemiotics to distinguish between (1) the "languaging" (Maturana 1988a, 1988b) of biological systems, (2) the sign games (Brier 1995) of bio-psychological systems, and finally (3) the language games (Wittgenstein 1963) of self-conscious linguistic human beings through the generalized media of socio-communicative systems (Luhmann 1995). A semiotic understanding can thus be integrated into Luhmann's conception, framing his theory within Peircean triadic metaphysics, see Figure 4.

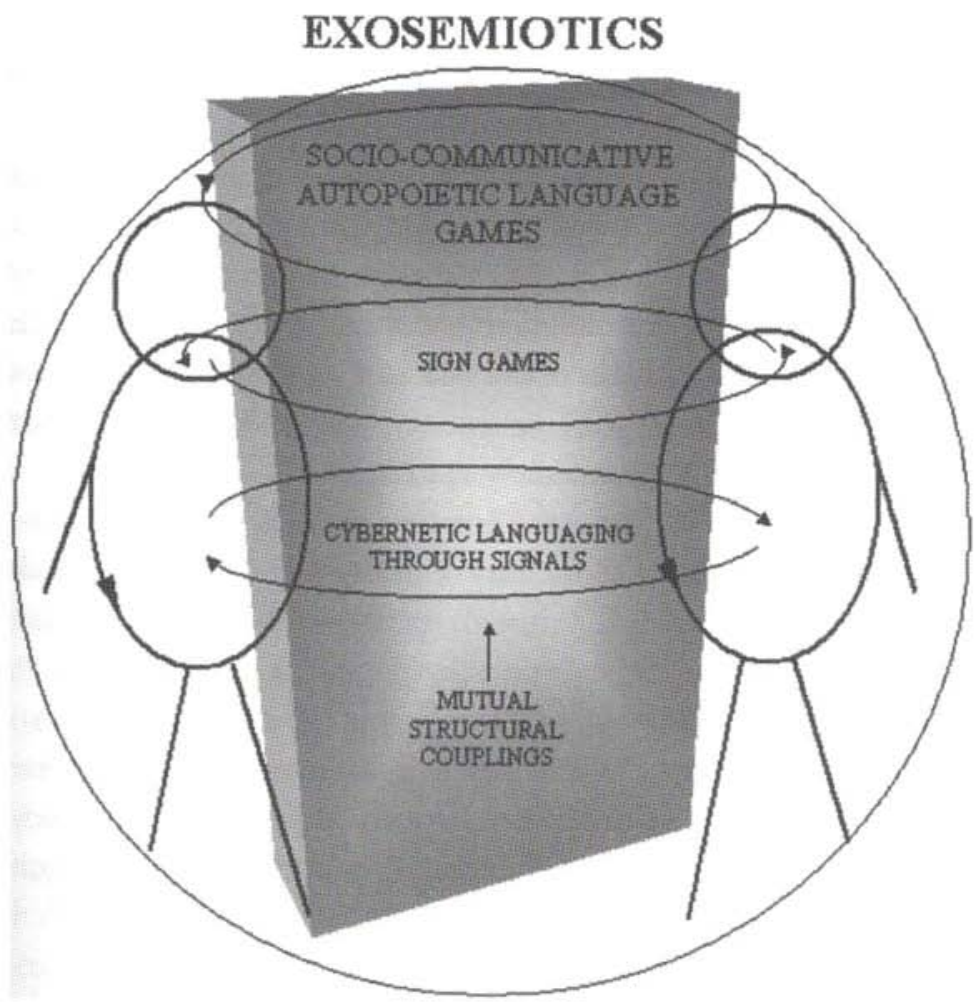

Figure 4. The three levels of communication in Lubmann's model semioticized. The informational structural couplings are inside buman language games and so are the sign games as they are always part of human face-to-face communication. Even in pure uritten communication, they are assumed in order to relate meaning to embodied human beings in intersubjective practices (From Brier 2008a).

On the basis of ethology and biosemiotics, human cognition may be seen to manifest itself as embodied semiosis, motivated by biological social interests that are powerful creators of structure and meaning in signification spheres. Most animal behaviour is also considered to be unconscious just like much of 
our linguistic categorizations and use of metaphors. Still, ethologists came to the realization that motivation is not a physiological concept (Hinde 1970). In human beings, sign games develop into language games. As we are born and grow within the context of human social communication the psyche is perfused with signs. Figure 4 shows the evolutionary levels. In human beings most of the sign games level has come under control of language-based human selfconsciousness, though not reflexes, which we have great trouble controlling. Thus the main part of our "body language", such as pre-linguistic intentional communication and mimesis, has been culturally influenced in its form and meaning (Brier 1981).

The signification sphere is a workable model of nature for living systems that, as species, existed and evolved through millions of years. It is also applicable to the human species, indicating that our languages have deep, inner connections to the ecologies of our cultures. An existing culture is a collective way for ensuring the survival of a social system. In other words, cultures have signification spheres that determine their ecosemiosis, and vice versa. These are largely created through the forms of life and language games of that culture, be they animistic in a hunter-gatherer society, or materialistic-energetic and informational in a post-industrial society like ours.

Meaning is then seen as generated by the interpenetration of systems. For example, language is a part of the socio-communicative system, but it does not really become meaningful before it interpenetrates with the psychic system and thus expresses differences of emotions, volitions and perceptions, "putting words" on our silent inner being. Our cognitive, emotional and volitional qualities would only have a weak connection to reality if they were not connected to the survival of the living system's organization as a body, in its interaction with environmental differences in the development of a signification sphere during the evolution of the species.

\section{The role of consciousness in signification}

Within a theory that accepts irreversible time and evolution as a basis for its ontology, consciousness must be taken to arise from physical systems such as bodily-based and integrated nervous systems. But in traditional science, including cognitive science, we are not given any explanation of how this takes place, or why consciousness exists at all. How could a physical system such as a brain also be an experiencer? Chalmers (1996) has called this "the hard problem" arising when consciousness is taken to be a natural phenomenon, falling under the sway of natural laws. But as he also points out, this is not to say that the 
natural laws concerning consciousness will have to be physical laws. As we have seen, it is difficult to see how consciousness should be explained within a physicalistic world view or even within an informational one, even if it is combined with systems theory, cybernetics and autopoiesis. Jackendoff (1987 in the foreword) wonders: what is the relationship between "the computational mind" and the "phenomenological mind", and thus conceives another problem: "the mind-mind problem". Mainstream (cognitive) science faces many other "hard problems": How can language evoke feelings, qualia and images? How can individual emotional purpose enter the nervous system and create semiotic interpretations? How can "free will" have causal influence? In brief: Why is all this physiological and information processing accompanied by an experienced inner life?

A shift to a semiotic worldview that is broad enough to contain cybernetics, information science, system theory, autopoiesis, complexity science and philosophy seems therefore worth a try. The laws of consciousness and signification might thus turn out to be semiotic evolutionary laws, as Peirce proposes in his evolutionary, pragmaticistic and triadic semiotics. A Cybersemiotic interpretation of Peircean semiotic philosophy then sees the unmanifest Firstness as a chaos of qualia, a basic form and feeling with the tendency to form habits. Matter is an "effete mind". Matter and mind are united in the continuum of Firstness and develop through "evolutionary law" into Secondness manifesting itself as resistance, force, dualistic concreteness, and the impenetrability of objects. Secondness provides what second-order cybernetics sees as constraints on perception and cognition occurring in semiosis. The mediation of Thirdness creates true triadic sign processes. The term "quasisemiotic objects" recognizes that systems in nature and culture work with differences and pattern fitting, often in the form of information instead of through either physical causality or meaningful semiosis. Ontologically, this can be taken to correspond to systems of Secondness having established an information level above the energetic and material level of nature. This area of objective information, delimited from a semiotic point of view, is part of what classical first-order cybernetics (cf. Brier 1991) considers its subject area: goaloriented machines and pattern-forming, self-organized processes in nature based on entropic information concepts. Cyber(bio)semiotics, on the other hand, suggests that what goes on inside the body between organs and tissues are not only informational processes but also biosemiotic ones. The sign vehicles are hormonal and transmitter molecules that are interpreted differently from tissue to tissue and from situation to situation. Since we now know that 
the hormone system, the immune system and the nervous system have receptors for each other's sign molecules, the total self-organized system can be called the biological self and is visualized in Figure 5 with the arrows around "endosemiotics".

The contemplating of spontaneous conscious feelings through semiotic thinking may then be called "phenosemiotics" (Brier 2008a). This is where we can imagine the psychological non-linguistic self. In Figure 5 phenosemiotics is shown in relation to Luhmann's psychic autopoietic system and between "thought semiotics" and "intrasemiotics". The latter provides a solution to the big mystery of dualism: how can there be communication between mind and body? The solution derives from the semiotic explanation that we here have two Levels or types of semiosis and not, as Descartes claimed, two qualitative different "worlds" (cf. Popper 1962, Zlatev this volume). The models build on Peirce's synechism. The connection is the structural coupling between endosemiotic and phenosemiotic processes or between the biological self and the phaneroscopic self through which semiotic communication goes on in the form of images, feelings, drives that are normally outside of conscious control.

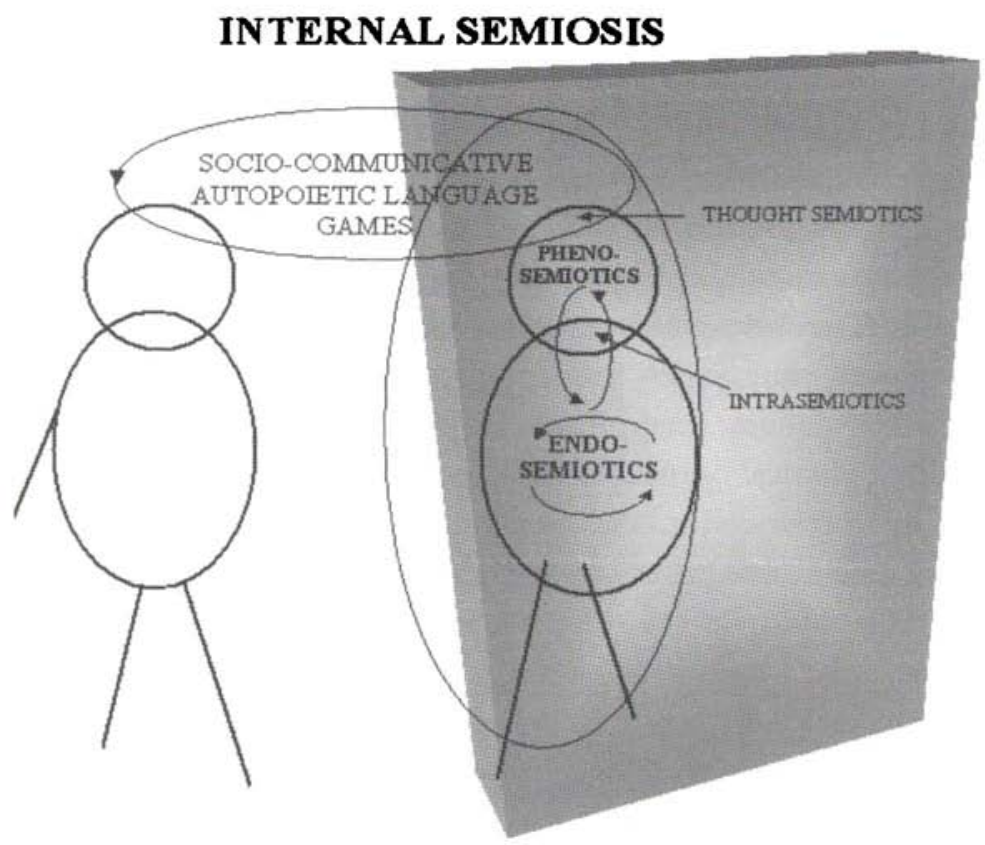

Figure 5. A schematic illustration of the relationship between phenosemiotics, endosemiotics, thought semiotics and intrasemiotics (From Brier 2008a). 
When language is used to conceptualize the images, feeling and willings of phenosemiotics we get yet another structural coupling that allows conceptual and linguistic thinking, which is in the figure called "thought semiotics". This is where human self-consciousness organizes itself through symbols. In the words of Peirce:

In what does the identity of man consist and where is the seat of the soul? It seems to me that these questions usually receive a very narrow answer. Why we used to read that the soul resides in a little organ of the brain no bigger than a pin's head. Most anthropologists now more rationally say that the soul is either spread over the whole body or is all in all and all in every part. But are we shut up in a box of flesh and blood? When I communicate my thought and my sentiments to a friend with whom I am in full sympathy, so that my feelings pass into him and I am conscious of what he feels, do I not live in his brain as well as in my own - most literally? [...] Each man has an identity which far transcends the mere animal; - an essence, a meaning subtle as it may be. He cannot know his own essential significance; [...] But that he truly has this outreaching identity - such as a word has - is the true and exact expression of the fact of sympathy, fellow feeling - together with all unselfish interests - and all that makes us feel that he has an absolute worth. [...] Whatever man is he is at each instant; [...] At each instant the only internal phenomena he presents are feeling, thought, attention; [...] Feelings, thought, attention are all cognitive; [...] All cognition is general, there is no intuition; A general representation is a symbol; [...] Every symbol has an essential comprehension which determines its identity. The confirmation I offered was the fact that man is conscious of his interpretant, - his own thought in another mind - I do not say immediately conscious - is happy in it, feels himself in some degree to be there. So that I believe that nothing but an undue ascendency of the animal life can prevent the reception of this truth. (Peirce CP 7.591)

Thus, I find the theory that self-consciousness - according to Peirce - is produced by the embodied experience of signs in the form of intersubjective symbols, to be a fruitful approach. This is, like scientific methods, an abductive and fallible process. How this process of combining the psychological or phenomenological self with language into a language-based self-consciousness goes on, is one of the great mysteries of cognitive science. Peirce offers a semiotic explanation. The contribution of the present article is to have combined this with Luhmann's autopoietic understanding of body, psyche and 
communicative meaning as well as the understanding of embodied semantics on an ethological and biosemiotic basis.

The conscious self must be the autopoietic-semiotic system of thought semiosis. Peirce writes further that the self is a symbol that contains all a man has thought in his life, and this self is also dialogical as it is in semiotic negotiation with itself:

We have already seen that every state of consciousness [is] an inference; so that life is but a sequence of inferences or a train of thought. At any instant then man is a thought, and as thought is a species of symbol, the general answer to the question what is man? is that he is a symbol To find a more specific answer we should compare man with some other symbol (Peirce CP 7.583.)

It should now be obvious that we cannot in a consistent way tell the story about ourselves as an embodied, linguistic and culturally competent and coded living system on the basis of a scientific approach, based on the assumption that there is no meaning whatsoever in nature. No evolutionary theory, including dialectical materialism and system-theoretical emergence, can fully explain how life, cognition, signification and consciousness developed without relating it to the basic knowledge of our lifeworld or signification sphere. How to make this integration is a main problem in both Husserl's and Peirce's work. Inspired by both, as well as Merleau-Ponty (1962), I conclude by offering a combined ontological and epistemological model of the relation between the many types of knowledge.

\section{The fourfold semiotic star}

The acceptance of the embodiment of mind - as it is also found in embodied cognitive semantics - implies a break with dualism, where mind is in another world than matter and body. It also leads to a break with the subject-object distinction as primary in making the distinction between system and environment, as also emphasized by Spencer-Brown (1997) and Luhmann (1990, 1992, 1995, 1999). But again: how can we explain the system's ability to observe if we take the world to be a purely material place? An answer is to see our semiotic, embodied, conscious, social practice as the centre of four different "worlds", as shown in Figure 6. 


\section{Consciousness}

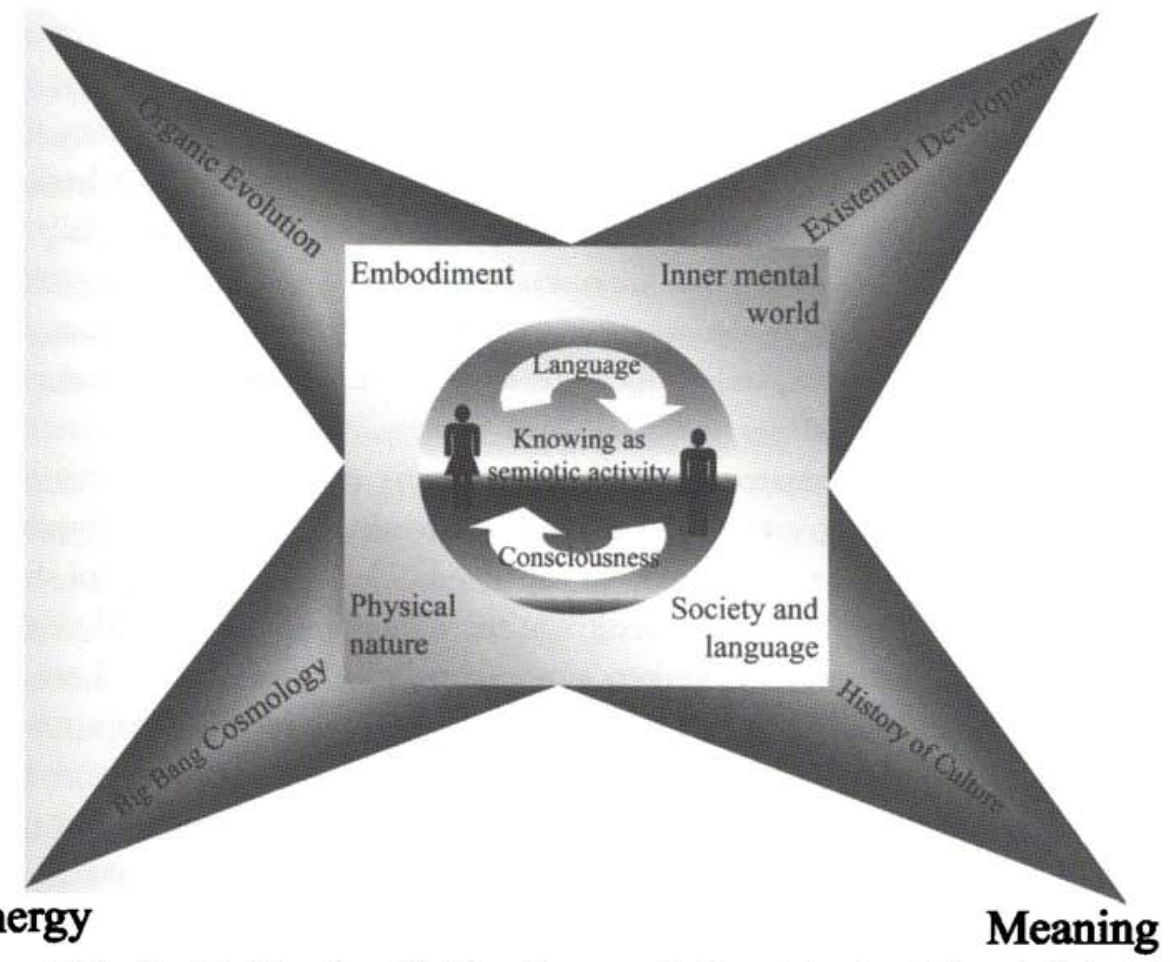

Figure 6. The Semiotic Star. A model of bow the communicative social system of the embodied mind produces four main areas of knowledge. Pbysical nature is usually explained as originating in energy and matter, living systems as emenging from the development of life processes (for instance, the first cell). Social culture is explained as founded on the development of meaning in language and practical babits, and finally our inner mental world is explained as deriving from the development of our individual life world and consciousness. But all these topes of knowledge bave their origin in our primary semiotic lifeworld (From Brier 2008a).

As a consequence of the broad agreement that human beings are embodied, feeling, and knowing cultural beings one can say that we therefore can be seen as living simultaneously in four different worlds:

1. Our body-hood as the source of life, which we share with other living species.

2. Our inner world of emotions, will, drives, affects and thoughts, manifested as mind and consciousness.

3. The physico-chemical-informational environment of the natural world.

4. The cultural world of language, meaning, power and technology such as the informational machines we call computers. 
Each of the four worlds has historically developed its own type of narrative, especially in its fundamentalistic and reductionistic versions. Physicists and chemists tend to view the universe as consisting of matter, energy, and meaningless information. Mechanical biologists continue this view into their area, but non-mechanical biologists tend to perceive the universe as basically animate (an "ecology of mind"). The social and cultural sciences, especially the dialectical and historical materialistic ones, as well as the radical social constructivistic ones, tend to see the world as constructed from social, human, and linguistic interpretations, unless they are dualistic, accepting that nature is as science describes it (Brier 2008c). Thus, Energy, Life, Consciousness and Meaning become separated in different domains or worlds. But this is a paradox, since we know from our everyday lifeworld, experienced in linguistic communication, that they are not so separated. The incompatibility of these four dominant views is a deep paradox in the modern scientific world view as well as in the so-called postmodern views of radical constructivism. I see the worlds as scientifically and rationally irreducible to each other in their present forms. Cyber(bio)semiotics can be seen as a new philosophical framework that attempts to avoid these inner inconsistencies. The philosophy and theory of a Peircean biosemiotics is unfortunately not yet fully developed by any of the current approaches, and some researchers within biosemiotics attempt to avoid the Peircean foundation in order not to challenge the received view of science and scientific knowledge too much (Brier 2008b). The present article presents an attempt to develop the theory a step further.

My suggestion is, in the spirit of phenomenology, to start in the middle, with our daily, lived semiotic and linguistic practice. Like Peirce, I see the semiotic mind at the heart of all four worlds. The basic question in any phenomenologically based philosophy of knowledge must further be from what or where the ability of the observer to produce knowledge and to reflect consciously on his knowledge in language comes from.

When accepting time's arrow and irreversibility (Prigogine \& Stengers 1984) as a prerequisite for cognitive processes to take place (Brier 2002), the question can be reformulated as follows: How did the first distinction of awareness come about and how did the world start? These questions have been separated in the combination of modern science and philosophy that forms our present worldview. The first question is answered in phenomenology and the other one in physics. I hold that our deepest problem in creating a coherent worldview to be how to integrate those two descriptions. Physics - especially quantum 
physics - has serious problems as how to integrate the observer within the observed.

Modern European phenomenology starting with Husserl developing through Heidegger and Merleau-Ponty and further into hermeneutics by Gadamar has had problems of establishing "the other" (1.e., intersubjectivity) and a world around the observer's consciousness (Zahavi 2003). I suggest that a combination of second-order cybernetics in all its aspects and a Peircean pragmaticistic triadic evolutionary semiotics gives best solution to this problem at present.

If one then asks the foundational question of any such philosophy in its combination of epistemology, ontology, ethics and aesthetics: What is before the beginning? In physics it means asking. What is before the Big Bang? In phenomenology and second-order cybernetics: What comes before the first distinction? In Peircean semiotics it amounts to asking. What is before the first semiosis? To such questions, one can only in an evolutionary science answer: there is (a) becoming! ${ }^{17}$

Perception and cognition, as forms of signification, demand irreversibility and thus: "the arrow of time". Knowledge generalizations will always have a degree of uncertainty in them. Signs are never the same as the reality of Secondness and can never give a complete and true picture of Firstness. Still they are the best stipulations of reality we have - including theories of levels of consciousness and signification - and in their Thirdness they are falsifiable when used to express arguments. This way we are assured of that minimum of realism that makes science and reason meaningful as a normative social commitment, which it is then up to the individual to interpret into the intersubjective knowledge of society, corresponding to Popper's (1962) "objective knowledge". Thus the process of knowing forces us to stipulate signs, signification, irreversible time and evolution that reflect back as an explanation on our own bodies. But evolutionary theory and the Big Bang are not theories that start from an observer standing at the beginning of time and therefore are not in the position of extrapolating everything from there in an absolutely true form, as is still the dream of many scientists such as Hawkins (1989) and Wilson (1999).

Thus Peirce's answer to this becoming of (what modernity would call) "the inner and the outer world" is in my interpretation the fundamental category of one can of course go further, which Peirce also does in his Panentheism (Brier 2008c). 
Firstness. ${ }^{18}$ It is not a "before" in the ordinary understanding of time. When becoming becomes aware and makes the distinction between itself and environment it projects an ontology, which does not mean a final and unchangeably true picture of the world or reality. It is a working hypothesis of reality including the other, language and ourselves, which we test and change. That is never done alone! As human observers we find ourselves in language and therefore in intersubjectivity with other linguistic beings and observers. We do not have to postulate the other after becoming aware of ourselves, because they are prerequisites for our becoming aware as linguistic self-conscious beings. Further we cannot talk of being without knowing. if we exist but do not know, our existence does not matter. A point illustrated in Figure 6 is that becoming aware forces us to postulate the other, our own self, our bodyhood, the environment and language.

Like Peirce, I take our basic emotions to be the (probably) rationally unexplainable building blocks of cognition and signification. Meaning and signs arise in the process of signification by relating the basic emotional experiences to each other. The single emotional experience has no meaning in itself. One of the strengths of Peirce's semiotic philosophy is that qualia and mind are "installed" in the metaphysics from the beginning. The reason that they cannot be explained as such is because they can only be deduced as a necessary prerequisite for the production of that knowledge the nature of which we wish to discuss, as I have argued in this article. ${ }^{19}$ To awaken to the world for human beings is to acknowledge that it has some kind of resistance and form reacting to our interactions with it (Secondness). These forms may be eigenforms of certain circular process involving our cognition. We do not know for certain, but nevertheless they are somewhat stable forms over time. This is what Peirce calls Thirdness resulting in habits of nature, which establishes time and include us and our cognition.

Thus from the standpoint of semiotics we can establish evolution as a theory of self-reflecting signification and therefore compatible with the social studies and humanities. The frustration of being human is that our knowledge of the lifeworld is fallible. But for Peirce it is our fallibility and the limits in our knowing that makes us individual human subjects.

18 Peirce's theory of agapism or evolutionary love is also important here but that will lead us into other long philosophical explanations, which I have worked out in Brier (2008c).

19 Further argumentation for this analysis and the Semiotic Star can is given by Brier (2008a). 


\section{References}

Bains, P. (2006). Tbe Primagy of Semiosis: An Ontology of Relations. Toronto: Toronto University Press.

Barbieri, M. (2001). The Organic Codes: The Birtb of Semantic Biology. Ancona: PeQuod. Republished in 2003 as: The Organic Codes. An Introduction to Semantic Biology. Cambridge: Cambridge University Press.

Barbieri, M. (2008). What is Biosemiotics? Biosemiotics 1, 1-3.

Bertalanffy, L. von (1976/68). General System Theory. Foundations, Development, Applications. New York: Braziller.

Brier, S. (1981). Om granser for sammenligning. Den komparative metode og spørgsmålet om humanetologiens genstand. Nicbe: Nordisk tidsskrift for kritisk biologi 2 (2), 96-151.

Brier, S. (1992). Information and Consciousness: A Critique of the Mechanistic foundation of the Concept of Information. Cybermetics \& Human Krowing 1 (2/3), $71-94$.

Brier, S. (1995). Cyber-Semiotics: On autopoiesis, code-duality and sign games in biosemiotics. Cybermetics of Human Krowing 3 (1), 3-14.

Brier, S. (1996). From Second-order Cybemetics to Cybersemiotics: A Semiotic Reentry into the Second-order Cybernetics of Heinz von Foerster. Systams Raseancb 13 (3), 229-244.

Brier, S. (1997). What is a Possible Ontological and Epistemological Framework for a True Universal Information Science': The Suggestion of Cybersemiotics. World Futures 49, 287-308.

Brier, S. (1998a). Cybersemiotics: a transdisciplinary framework for information studies, BioSystems 46, 185-191.

Brier, S. (1998b). The Cybersemiotic Explanation of the Emergence of Cognition: The Explanation of Cognition, Signification and Communication in a non-Cartesian Cognitive biology. Evolution and Cognition 4 (1), 90-102.

Brier, S. (1999). Biosemiotics and the foundation of cybersemiotics. Reconceptualizing the insights of Ethology, second order cybernetics and Peirce's semiotics in biosemiotics to create a non-Cartesian information science. Semiotica 127 (1/4), 169 198. Special issue on Biosemiotics.

Brier, S. (2000). Biosemiotic as a possible Bridge between Embodiment in cognitive Semantics and the Motivation concept of Animal cognition in Ethology. Cybermetics \&. Human Krowing 7(1), 57-75.

Brier, S. (2001a). Cybersemiotics and Umweltslehre. Semiotica 134 (1/4), 779-814.

Brier, S. (2002). Varela's contribution to the creation of Cybersemiotics: The calculus of self-reference. ASC-column, Cybernetics \& Human Knowing 9 (2), 77-82.

Brier, S. (2005). Third Culture: Cybersemiotic's inclusion of a Biosemiotic Theory of Mind. Axiomathes 15, 211-228.

Brier, S. (2006). The necessity of Trans-Scientific Frameworks for doing Interdisciplinary Research. Kybemetes 3-4, 403-425.

Brier, S. (2007). Applying Luhmann's system theory as part of a transdisciplinary frame for communication science. Cybernetics \& Human Knowing 14 (2-3), 29-65.

Brier, S. (2008a). Cybersemiotics: Why Information Is Not Enough (Toronto Studies in Semiotics and Communication). Toronto: University of Toronto Press.

Brier, S. (2008b). A Paradigm for Biosemiotics. Signs 2008, 30-81. Available online at <vip.db.dk/signs/artikler/Brier\%20(2008) \%20the $\% 20$ paradigm $\% 20$ of $\% 20$ peircean 
$\%$ 20biosemiotics.pdf $>(15 / 6 / 2009)$.

Brier, S. (2008c). Bateson and Peirce on the pattern that connects and the sacred. In J. Hoffmeyer (Ed.): A Logag for Living Systems: Gragory Bateson as a precursor for biosensiotic thinking (Chapter 12, pp. 229-255), Biosemiotics 2. London: Springer Vedag.

Brier, S. (2008d). A Peircean Panentheist Scientific Mysticism. Intornational Jownal of Transpersonal Studies (27), $20-45$.

Chalmers, D. J. (1996). Tbe Conscious mind. In Searcb of a Fundamental Tbeory. New York and Oxford: Oxford University Press.

Damasio, A. (2000). The Feeling of What Happens: Body, Emotion and the Mating of Consciousmess. New York: Harvester.

Deacon, T. W. (2007). Shannon - Boltzmann - Darwin: Redefining information (Part I). Cognitive Semiotics 1, 123-148.

Deacon, T W. (2008). Shannon - Boltzmann - Darwin: Redefining information (Part II). Cognitive Semiotics 2, 169-196.

Dennett, D. C. (1991). Consciousness Explained New York: Back Bay Books.

Ellis, R. D. \& Newton, N. (1998). Three Paradoxes of Phenomenal Consciousness: Bridging the Explanatory Gap. Joumal of Consciousness Studies 5 (4), 419-42.

Emmeche, C. (1998). Defining Life as a Semiotic Phenomenon. Cybemetics \& Human Krowing 5 (1) $33-42$.

Emmeche, C. (2007). On the Biosemiotic nature of Embodiment and our Cyborg Nature. In T. Ziemke, J. Zlatev \& R. Frank (Eds.), Body, Langrage and Mind Vol 1. Embodiment (pp. 379-410). Berlin: Mouton.

Favareau, D. (2008). The biosemiotic Turn: a Brief history of the Sign Concept in PreModernist Science. Biosemiotics 1, 5-23.

Foerster, H. von (1984). Observing Systems (The Systems Inquiry Series). California, USA: Intersystems Publications.

Gallese, V. \& Lakoff, G. (2005). The Brain's Concepts: The Role of the Sensory-Motor System in Reason and Language. Cognitive Nexropsycbology 22, 455-479.

Gardner, H. (1985). The Mind's New Science: A History of the cogrative revolution. New York: Basic Books.

Hinde, R. (1970). Animal Behaviour. A Synthesis of Etbology and Comparative bebaviour, Tokyo: McGraw-Hill. (International Student Edition).

Hoffmeyer, J. (1996). Signs of Meaning in the Universe. Bloomington: Indiana University Press.

Hoffmeyer, J. (2008). Biosemiotics: An Examination into the Signs of Life and the Life of Signs. Scranton, USA: Scranton University Press.

Hoffmeyer, J. \& Emmeche, C. (1991). Code-Duality and the Semiotics of Nature. In M. Anderson \& F. Merrell (Eds.), On Semiotic Modeling (pp. 117-166). Berlin: Mouton de Gruyter.

Husserl, E. (1997). Fanomonologiens idé (Die Idee der Phenomenologie). Copenhagen: Hans Reitzels forlag.

Husserl, E. (1999). Cartesianske Meditationer (Cartesianische Meditationen). Copenhagen: Hans Reitzels forlag.

Innis, R. E. (1994). Consciousness and the phay of Signs. Bloomington and Indianapolis: Indiana University Press.

Jackendoff, R. (1987). Consciousness and the Computational Brain. Cambridge, MA: MIT Press.

Johnson, M. (1987). The Body in the Mind. Chicago: University of Chicago Press. 
Hawkings, S. W. (1989). A Brief History of Time. Updated and expanded to anniversary edition. New York: Bantam Books.

Kauffman, S. (1995). At Home in the Universe. Oxford: Oxford University Press.

Kull, K. (1999). Biosemiotics in the twentieth century: a view from biology. Semiotica $127(1 / 4), 385-414$.

Lakoff, G. (1987). Women, Fire and Dangerous Tbings: What Categories Reveal about the Mind. Chicago: University of Chicago Press.

Lakoff, G. \& Johnson, M. (1980). Metapbors We Live By. Chicago: University of Chicago Press.

Lakoff, G. \& Johnson, M. (1999). Pbilosopby in the Flesb: The Embodied Mind and its Challenge to Westem Tbougbt. New York: Basic Books.

Leontev, A. N. (1977). Problemer id et pyjkiskes udvikling Vol. I-III. Copenhagen/Moscow: Sputnik/Progress(Original Russian, 1959).

Loren, K. (1977). Bebind the Mirror a searcb for a natural bistory of buman knowledge. London: Methuen \& Co Ltd.

Luhmann, N. (1990). Essays on Seff-Reference. New York: Colombia University Press.

Luhmann, N. (1992). What is communication? Communication Theory 2 (3), August 1972, 251-258.

Luhmann, N. (1995). Social Systems. Stanford, CA: Stanford University Press

Luhmann, N. (1999). Sign as Form. Cybermetics \& Human Krowing 6 (3), 21-37. Special Issue: Luhmann: Cybernetics, Systems and Semiotics.

Maturana, H. R. (1988a). Ontology of observing: The Biological Foundation of Self Consciousness and the Physical Domain of Existence. The Irish Joumal of Psychology 9 (1), 25-82.

Matumana, H. R. (1988b). Reality: The Search for Objectivity, or the Quest for a Compelling Argument. Irish Joumal of Pychology 9 (1), 25-82

Maturana, H. R. \& Varela, F. (1980). Autopoiesis and Cognition: Tbe realization of the Living. London: Reidel.

Maturana, H. R \& Varela, F. (1986). Tree of knowledge: Biological Roots of Human Understanding. London: Shambhala Publishers.

Medeau-Ponty, M. (1966). Phenomenology of Perception. Translated by C. Smith. London: Routledge \& Kegan Paul. Originally published as Pbenomenologie de la Perception (Paris, Gallimard, 1945).

Madenov, I. (2004). The Method of Conceptualizing Signs from Everyday Life

(On Charles S. Peirce's Marginalia). Internet-Zeitscbrift für Kulturusissenschaften 15 Juni 2004). Online at <www.inst.at/trans/15Nr/01_2/mladenov15.htm> (15/6/2009).

Nöth, W. (2001a). Introduction to Ecosemiosis. In E. Tarasti (Ed), Ecosemiotics: Studies in Envinonmental Semiosis, Semiotics of the Biogybermetic Bodies, Human/too Human/Post Human (pp. 107-123). ISI Congress papers, Nordic Baltic Summer Institute for Semiotic and Structural Studies Part IV, June 12-21 2001 in Imatra, Finland.

Peirce, C. S. (1931-58). Collected Papers vol I-VTII. Cambridge MA: Harvard University Press. Used here is Peirce (1994 [1866-1913]). The Collected Papers of Charles Sanders Peirce. Electronic edition reproducing Vols. I-VI ed. Charles Hartshome \& Paul Weiss (Cambridge: Harvard University Press, 1931-1935), Vols. VII-VIII ed. Arthur W. Burks (same publisher, 1958). Charlottesville: Intelex Corporation.

Prigogine, I. (1980). From Being to Becoming. San Francisco: W. H. Freeman.

Prigogine, I. (1996). The End of Certainty. Time, Chaos, and the New Laws of Nature. New York: The Free Press. 
Prigogine, I. \& Stengers, I. (1984). Onder Out of Cbaos: Man's New Dialogue with Natwre. New York: Bantam Books.

Schrödinger, E. (2006/1967). What is Life? Cambridge: Cambridge University Press.

Short, T. L (2007). Peirce's Tbeory of Sigus. Cambridge: Cambridge University Press.

Sonesson, G. (2006). The meaning of meaning in biology and cognitive science. Sign System Studies 34 (1), 135-213.

Spencer-Brown, G. (1979). Laws of Form. New York: E. P. Dutton.

Stonier, T. (1990). Information and the Internal Structure of the Universe: an exploration into information pbysics. London: Springer Verlag.

Stonier, T. (1992). Beyond Information: The Natural History of Intelligence. London: Springer Verlag.

Stonier, T. (1997). Information and Meaning: An Evolutionary Perspective. Berlin: Springer Verlag.

Zahavi, D. (2003). Fanomenologi. Copenhagen: Roskilde Universitetsforlag.

Zlatev, J. (2008a). The Dialectics of Consciousness and Language. Joumal of Consciousmess Studies $15(0), 5-14$.

Zlatev, J. (2008b). The Dependence of Language on Consciousness. Joumal of Consciousness Studies $15(6), 34-62$.

Wittgenstein, L. (1963). Pbilosopbical Investigations. Translated by G. E. M. Anscombe. Oxford: Basil Blackwell. 